Swarthmore College

Works

\title{
The Peace People: Principled And Revolutionary Non-Violence In Northern Ireland
}

Lee A. Smithey

Swarthmore College, Ismithe1@swarthmore.edu

Follow this and additional works at: https://works.swarthmore.edu/fac-soc-anth

Part of the Sociology Commons

\section{Recommended Citation}

Lee A. Smithey. (2017). "The Peace People: Principled And Revolutionary Non-Violence In Northern Ireland". The Troubles In Northern Ireland And Theories Of Social Movements.

https://works.swarthmore.edu/fac-soc-anth/174

\section{(i) ()}

This work is licensed under a Creative Commons Attribution-Noncommercial-No Derivative Works 3.0 License. This work is brought to you for free by Swarthmore College Libraries' Works. It has been accepted for inclusion in Sociology \& Anthropology Faculty Works by an authorized administrator of Works. For more information, please contactmyworks@swarthmore.edu. 
ing

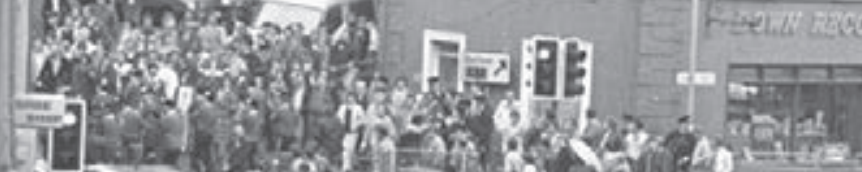

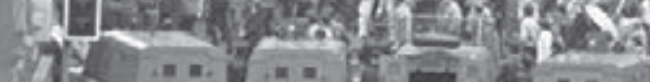

\section{1}

Ais:

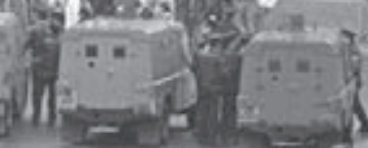

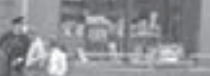

1

aris

BNist

In:

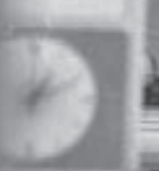

$H=1$

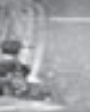

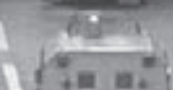
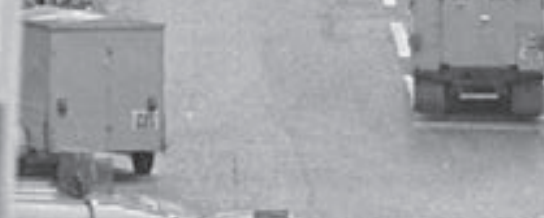

1)

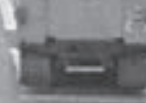

3
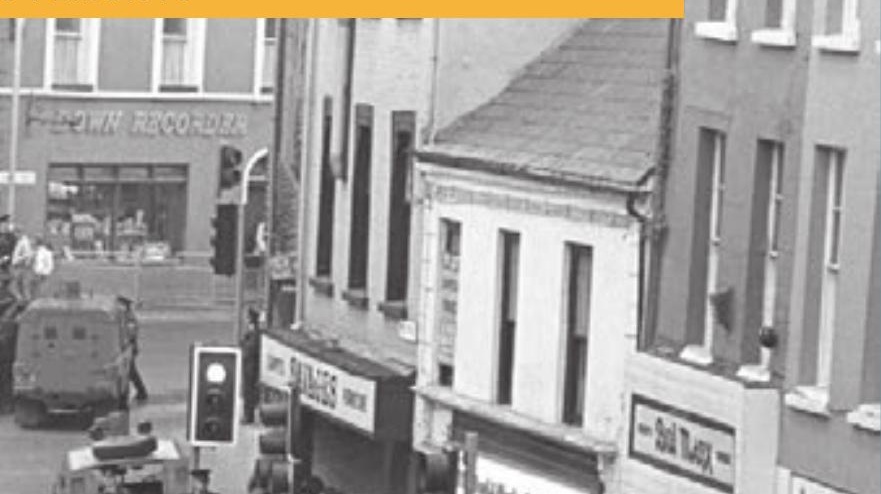

a nom 1
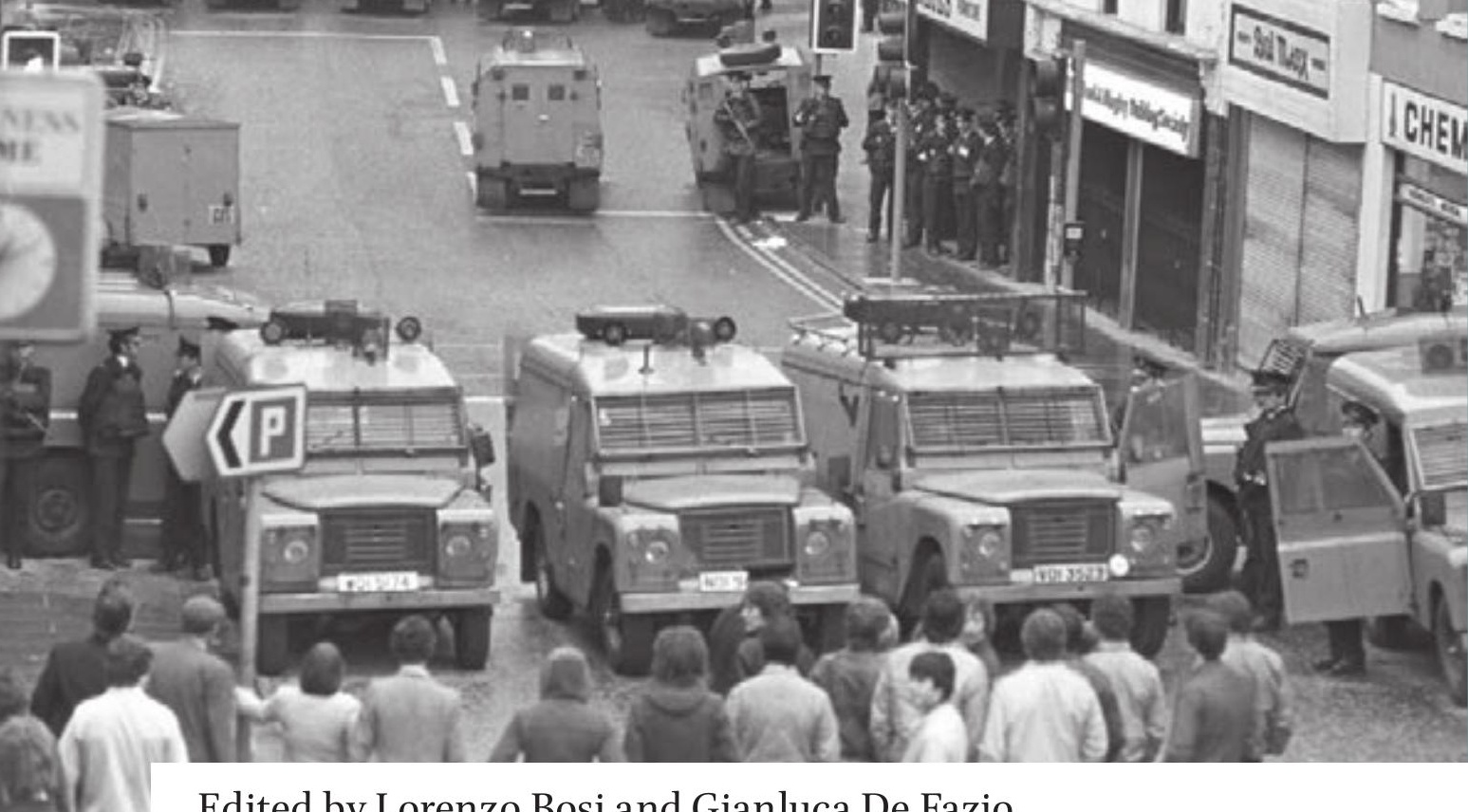

Edited by Lorenzo Bosi and Gianluca De Fazio

The Troubles in Northern Ireland and Theories of Social Movements

Amsterdam

University

Press 


\title{
The Troubles in Northern Ireland and Theories of Social Movements
}

\author{
Edited by \\ Lorenzo Bosi and Gianluca De Fazio
}


Cover illustration: Two rows of RUC Land Rovers keeping warring factions, the Nationalists (near the camera) and Loyalists, apart on Irish Street, Downpatrick. bho1o64

Bobbie Hanvey Photographic Archives (MS2001.039), John J. Burns Library, Boston College

Cover design: Coördesign, Leiden

Typesetting: Crius Group, Hulshout

Amsterdam University Press English-language titles are distributed in the US and Canada by the University of Chicago Press.

$\begin{array}{ll}\text { ISBN } & 978 \text { 90 } 89649591 \\ \text { e-ISBN } & 9789048528639 \text { (pdf) } \\ \text { DOI } & 10.5117 / 9789089649591 \\ \text { NUR } & 686\end{array}$

\section{(c) $\left(\mathrm{BP} \Theta_{\mathrm{NC}}\right.$}

Creative Commons License CC BY NC ND (http://creativecommons.org/licenses/by-nc-nd/3.o)

@ All authors / Amsterdam University Press B.V., Amsterdam, 2017

Some rights reserved. Without limiting the rights under copyright reserved above, any part of this book may be reproduced, stored in or introduced into a retrieval system, or transmitted, in any form or by any means (electronic, mechanical, photocopying, recording or otherwise). 


\title{
11 The Peace People
}

\author{
Principled and Revolutionary Non-violence in Northern \\ Ireland $^{1}$
}

Lee A. Smithey

The Peace People movement emerged in 1976 in response to a wave of intense violence that had grown in Northern Ireland since 1969. The movement quickly drew large crowds at mass rallies to protest violence, attracting international attention. Many of the people of Northern Ireland seemed ready to challenge the status quo of violence and sectarianism that had come to dominate everyday life. The Peace People movement, or the 'Community of the Peace People', adopted non-violent tactics and a non-violent ideology, challenged all forms of violence, worked to develop a democratic social movement organization, supported community relations and community development work, and called for a new unifying Northern Irish identity.

In the early stages of the movement, mass rallies were well-attended by both Catholics and Protestants. Enthusiasm ran high, and the movement enjoyed substantial support both at home and abroad. Indeed, Betty Williams and Mairead Corrigan, two of the movement's leaders, received the 1976 Nobel Peace Prize. During the second phase of the movement, the leaders proposed an expansive plan for grass-roots transformation of the region, both politically and culturally. However, two years later, the organization suffered from financial challenges, and internal dissension came to a head.

The energy of the movement's launch and the scope of the Peace People programme were remarkable. During the first phase of rallies, it was as if the normal ethnonational fault lines became less salient in a liminal moment as tens of thousands of people joined together in public demonstrations. Ciaran McKeown, Mairead Corrigan, and Betty Williams sought to provide direction and leadership in this unusual moment of collective emotional outpouring. Through the organization, they also worked to build

1 Sections of this chapter also appear in Smithey (2009). The author thanks Anne Kane, Lester Kurtz, Rob Fairmichael, and Matt Meyer for feedback on earlier drafts of this chapter. Any mistakes belong to the author. The Swarthmore College Peace Collection provided access to the newsletters of the Peace People organization. 
further participation, a democratically elected central social movement organization, a network of community-based chapters, and a constructive programme to address contemporary social issues. All the while, they hitched their work to the transnational peace movement, establishing relationships with prominent peace activists and organizations in the United States, Latin America, Europe, and the Middle East. The Peace People movement constituted a significant challenge to political violence in a region wracked with bombings, assassinations, and covert and overt military operations. The leadership envisioned an end to violence; transformation of longstanding sectarian divisions; social, political, and economic reform; a new Northern Irish identity; and a new local political system, all achieved through non-violent organizing within a framework of love and respect for humanity. Participants were initially optimistic about the movement's potential, though some observers remained guardedly pessimistic, expecting the movement to quickly disappear as other grass-roots interventions had done. Politicians initially dismissed the movement's potential, but later became frustrated with their inability to co-opt it. The Peace People were not following the usual sectarian and political scripts employed by other political actors, and this afforded a novelty that appealed to many otherwise disillusioned citizens.

As the editors explained in their introduction, this long-awaited volume brings together social movement research and scholarship on divided societies, encouraging us to think more deeply about how social movements play important roles in what are often called 'intractable' identity conflicts and how the dynamics of such conflicts shape collective action. They furthermore highlight the importance of 'actor-based approaches' and the 'contextualizing of contentious politics'. In this chapter, we examine a social movement with leaders who sought to overcome ethnonational identity barriers, rejuvenate local democracy, and further a global peace and justice movement. To understand its emergence and decline, it is important to take into account historical, political, and socio-economic conditions as well as movement strategy and cognitive and cultural forces. The Peace People constituted a direct non-violent response to violent conflict that had deepened ethnonational division. However, the strategic and ideological choices that movement leaders made to embrace non-violent methods and praxes proved crucial in shaping the trajectory of the movement.

The movement has been documented by McKeown (1984), Fairmichael (1987), and Deutsch (1977), though it has rarely been taken up in academic literature and usually only evokes passing reference by historians. The case could lend itself to a range of analyses of leadership, organizational 
structures, transnational movement, gender studies, conflict transformation, and more. Here, I focus on the cognitive and cultural dimensions of the relationship between the expansive programme laid out by Williams, Corrigan, and McKeown (the latter two in particular) and movement participants.

Cultural considerations have become well-grounded in the study of social movements, and as I have argued elsewhere (Smithey 2009), sociologists are now beginning to turn their attention towards the cultural implications of the methods that social movement organizations employ, including the use of non-violent action. This is an exciting new vista of research that views conflict as a culturally rich form of interaction within and between contending parties. It is important to remember, however, that the effects of the framing work and strategic action decisions that movement leaders make are contingent on the socio-historical contexts in which movements emerge, the cultural terrain that both enables and constrains movements. In the case of the Peace People, their far-reaching non-violent agenda allowed them to distance themselves from the usual spiral of ethnonational conflict that wracked the region, but it also proved difficult to sustain.

The Peace People represented what Nagle (in this volume) calls a 'transformationist' social movement. Much as the trade union movement in post-accord Northern Ireland has worked to challenge sectarianism through appeals to class identity and a common humanity, the nonviolent programme and ideology advocated by the Peace People movement leadership aimed to transform the familiar sectarian terrain of Northern Ireland. They called for a new post-sectarian identity and new political systems decoupled from ethnonational divisions. Whether and how such a revolutionary programme of non-violent transformation could be made to resonate broadly in the midst of an 'intractable' ethnonational conflict constitutes the particular focus of this chapter.

Ethnonational identities often become monolithic and polarized in the heat and trauma of violent conflicts, and trying to soften or diversify collective identities is a common goal of conflict transformation efforts. Fortunately, collective identities are malleable, but only within limits (Todd 2005; Jenkins 2008; Wimmer 2008). Through framing processes, movement leaders can work to shift the cultural terrain of collective identities, prioritizing some over others. However, such transformative work is never unconstrained. It takes place within a field of historical experience, countervailing identities, and predispositions. Leaders with a deep understanding of their own in-groups often have the cultural capital to introduce new interpretations of where group boundaries lie. Such change 
is incremental, and leaders can stretch their constituents too far when they call them to radical new interpretations of collective identities that outpace constituents' abilities to reconcile the new models with those they have already internalized (Smithey 2011). Certainly, many factors were responsible for the Peace People's downturn, including internal contention, funding problems, and leadership challenges (Fairmichael 1987), but this chapter will focus on the crucial interaction between the principled and revolutionary non-violence that the movement's leaders envisioned and cultural and ideological preferences in Northern Ireland. ${ }^{2}$

After relaying the series of events that led to the rapid rise of the Peace People and the two main phases of the movement's development, I present the framing of movement values and goals as an important process through which to observe the challenges movements face when trying to overcome centrifugal forces of division in the midst of a violent ethnonational conflict. Moreover, I argue that the leaders of the Peace People called participants not just to non-violent action but to extensive ideological commitments to principled and revolutionary non-violence. They aimed to escape the relentless pull of everyday violence and trauma, a broken political system, and polarized collective identities, but their goals proved too great a departure from the lived experience and habitus of many in Northern Ireland.

\section{The Peace People}

On Wednesday, 11 August 1976, one day after a car chase resulted in the fatal shooting of an Irish republican Army (IRA) volunteer by the British military and the deaths of three children, 50 women in the republican neighbourhoods of Andersontown and Stewartstown in Belfast protested republican violence by marching with baby carriages. Later that evening, Mairead Corrigan, ${ }^{3}$ an aunt of the children, appeared on television, pleading for an end to violence. Betty Williams took action door to door in her neighbourhood with a petition protesting paramilitary violence. By the following evening (Thursday), Williams had collected 6ooo signatures (Deutsch 1977: 6). She also scheduled a rally to take place the next day

2 The analysis I offer draws on secondary literature about the Peace People movement, published first-hand accounts by activists and observers, and articles from The Times of London, and the movement newsletter, Peace by Peace (1976-1978).

3 Mairead Corrigan later married her sister's husband after her sister's death, and she is therefore referred to in more recent literature as Mairead Corrigan Maguire. 
in Andersontown. Ten to fifteen thousand women, both Protestant and Catholic, attended (McKeown 1984: 142-143).

Corrigan and Williams were generally recognized as the leaders during the early months of the movement, and Ciaran McKeown, a journalist and non-violent activist, soon joined them in leading the movement for the next three and a half years. The first movement participants were almost exclusively women, and the press often referred to the movement as the 'womens' movement' (Walker 1976b). The leaders promptly sought to include all citizens, and they adopted the name, 'Peace People'.

\section{Phase One - Rallies}

The initial phase of movement activity extended from the first rally in West Belfast on 14 August 1976 through a rally in Drogheda in the Republic of Ireland on 5 December 1976. At least 26 marches or rallies took place in Northern Ireland, Britain, and the Republic of Ireland, attracting intense international media attention and international financial and political support. Meanwhile, 'Peace Committees' or local groups (110 by one count) sprang up in communities as participants in the rallies organized themselves, and a group development programme was arranged to support local organizations (Deutsch 1977:159; Fairmichael 1987:13). The leaders secured a meagre central office in Belfast to facilitate communication between the various peace committees that formed and established an Assembly and Executive committee.

The first rally boasted between 10,000 and 15,000 participants (Geddes 1976a; McKeown 1984). The rally on 21 August in Protestant East Belfast involved more than 20,000 people, and the rallies on Belfast's Shankill Road and in Derry/Londonderry each attracted around 25,000 participants (Geddes 1976b; Walker 1976b). These were the largest, but other marches and rallies across Britain, Northern Ireland, and the Republic of Ireland involved thousands more participants. Fairmichael (1987:6) estimates roughly that 100,000 people in Northern Ireland (approximately 6.5 per cent of the population) attended at least one rally. The death of the Maguire children had revealed collective concerns within the war-weary public about the continuing violence, and the rallies became catalytic rituals through which many in Northern Ireland sought to reframe the boundaries of acceptable political action and surmount deeply entrenched ethnic and political divisions.

The movement also attracted international media attention. Camera crews arrived from the United States and European countries to document 
the movement's activities. McKeown, Williams, and Corrigan travelled to the United States on at least two occasions for television interviews and meetings with members of Congress, including Senator Edward Kennedy. The Norwegian People's Peace Prize, organized by Norwegian media, raised more than $£ 200,000$ for the movement by December 1976, and Corrigan and Williams received the 1976 Nobel Peace Prize in December 1977.

\section{Phase Two - Community Politics}

The second phase of the movement began in early January 1977 as the leadership organized for the long-term maintenance of the movement and set out goals that would fulfil their vision of grass-roots transformation. Community peace groups had formed during the rally phase, and the leadership planned to coordinate them in a bid to create new 'community politics' and a shared 'Northern Irish' identity that would transcend polarized political identities (McKeown 1976: 24-25; 1984: 1, 4). In McKeown's (1984:189) words:

Our more immediate concern was with the low-level application of these ideas in the wake of 'hot war' [...] Our purpose was to encourage such neighbours to take an active interest in the quality of life of their own streets and districts, to feel that they had friends in other communities busy in the same genuine patriotism, and that together they would defeat the deepest law of repression, 'whatever you say, say nothing'.

To support this programme of grass-roots transformation, a non-profit company and trust were set up to disburse funds to community improvement programmes and small businesses. An 'escape route' was established to relocate those who wanted to defect from paramilitary organizations. At the same time, effort was directed towards establishing a sustainable organization to coordinate efforts. The strategy was designed to encourage a measure of self-esteem and mutual identification among the people of Northern Ireland that would eventually erode the sectarian bases for continuing violence and establish a social, political, and economic platform for self-governance.

However, over time, the movement began to experience difficulties among the leadership and community groups, many of which faltered after the rally phase. A train was chartered to take members to a rally in Dublin on 18 February 1978, but by then, many had lost interest, and the event was not considered as successful as earlier rallies (Walker 1978). Concern arose over the use of funds, including the Nobel Peace Prize award 
to Corrigan and Williams. Controversy also developed over McKeown's prominence in decision-making and the organization's fiscal strategy as limited funds ran short and loans were written off (Deutsch 1977; McKeown 1984). To demonstrate their faith in the democratic structures that had been established and to encourage greater grass-roots ownership of the programme, McKeown, Corrigan, and Williams all resigned from the Executive committee in October 1978. Peter MacLachlan, formerly a prominent unionist politician, took over the chairmanship of the Executive.

\section{Framing Non-violent Revolution in a Divided Society}

Meaning making has become a central task of the study of social movements. Social movements introduce new narratives and discourses that are no less important than the demands they make of their opponents. They engage in 'framing' battles as they seek to legitimate new policies and often lifestyles and delegitimize those of their opponents. To mobilize participants, movement leaders develop frames and narratives about themselves and their opponents that resonate with potential movement members. In their early groundbreaking work on framing, Hunt, Benford, and Snow (1994) describe a 'frame alignment process' 'by which social movement organizations (SMO) seek to bring the beliefs and attitudes of potential recruits into sync with the ideological frame of the movement' (Hunt, Benford, and Snow 1994; McAdam, McCarthy, and Zald 1988: 725). A major element of the process is the creation (or realignment) of in-group and out-group identities (Hunt, Benford, and Snow 1994: 193-194). They stress that this process of identity formation is ongoing and that SMOs must be persistent if they hope to succeed.

However, framing contests take place in pre-existing fields of collective identities, preferences, and interests. The alignment of movement goals with pre-existing narratives, discourses, and identities is a particularly important challenge (Woehrle, Coy, and Maney 2008). Eyerman and Jamison (1991: 5657) stress the compatibility of the movement's message with contemporary norms and cultural expectations, or the 'willingness and capacity of the entire social formation to absorb, incorporate, or reject the "message" of the movement'.

Cognitive dissonance can set in when a movement's ideological basis or praxis ${ }^{4}$ conflicts with participants' pre-existing cognitions. As a movement's

4 Eyerman and Jamison (1991: 46) define praxis as a "'packages of ideas" or clusters of issues, or, perhaps most ambitiously, as organizational ideologies or profiles'. 
ideology and frames must compete in a cultural and political space against other competing ideologies and norms, we should explore successes and failures in these battles of ideas. The relationship between movement praxis and the level of integration among movement participants also becomes particularly relevant when studying the Peace People's efforts to reach their stated goals of a radical new democracy in a highly segregated society. I focus in this chapter on a particular set of non-violent praxes, principled and revolutionary non-violence, that served as central ideologies in the Peace People movement.

\section{Principled Non-violence}

'Principled non-violence' refers to an ideology or system of ideas and beliefs that accompany and legitimate the use of non-violent civil resistance while calling adherents to repudiate violence and encourage pre-figurative collective action. A brief look at several central elements of Gandhi's non-violent philosophy help illuminate the basics of principled non-violence (Gandhi 1962, 1967, 1986; Kurtz 2008). For principled activists, non-violence:

- is spiritual or metaphysical;

- is ethically or morally superior to the use of violence;

- should be practiced as a lifestyle;

- can produce new societal paradigms;

- separates the doer (opponent) from their deeds (oppression);

- assumes a oneness among humans.

Principled non-violence is both a strategy and a belief system. Adherents to principled non-violence reject the use of violence on moral and ethical grounds and insist that violence is ultimately more destructive than productive. Thus, means and ends become inseparable. Those who advocate principled non-violence emphasis its moral and strategic superiority for achieving the interests of their group and, ultimately, even their opponents.

\section{Revolutionary Non-violence}

The Peace People leadership also called for revolutionary non-violence, a praxis that shares many of the fundamentals of strategic non-violent action and principled non-violence. ${ }^{5}$ According to the peace activist, scholar, and

5 The now familiar distinction between strategic and principled nonviolence should not imply that non-violent revolutionaries are without strategy or principles. 
educator Matt Meyer, 'Revolutionary nonviolence emphasizes unity among radicals and proposes a militant non-violent praxis based on revolutionary transformation and mass civil resistance. ${ }^{6}$ Meyer (2014) asserts that revolutionary non-violence requires careful introspection of structural violence, colonial histories, and power structures. And while it might be argued that the Peace People side-stepped issues of colonial history in Ireland, the leadership felt that an end to violence would be necessary but not sufficient. A lasting peace would require root-and-branch transformation of politics, economics, and social relations through mass organizing and grass-roots action.

The organization's newsletter reveals consistent efforts to express solidarity with contemporary activists and movements often associated with revolutionary non-violence, such as the Plowshares movement, Movement for a New Society, advocates of Catholic liberation theology, and non-violent revolutionaries, such as the Berrigan Brothers and Steve Biko in South Africa (Meyer 2014). Many of the Peace People were inclined to participate in local social work, community development activities, or mass rallies, but a revolutionary programme that sought to address global economic disparities or authoritarianism in other countries proved elusive and even offensive to some.

\section{The Peace People and Principled Non-violence}

From the beginning, the main leaders embraced a radical non-violent ideology. Betty Williams' initial efforts gathering signatures for a petition protesting the death of the Maguire children expressed a simple desire for an end to violence and the dissolution of the IRA. She declared, 'After such a tragedy, we must and will have peace!' (Deutsch 1977:6). Mairead Corrigan responded boldly to threats by the IRA: 'We realize that before this is finished people may have to die for peace in Northern Ireland. But this only makes us more determined than ever, as none of us can think of a better cause to have to die for' (Walker 1976a). Ciaran McKeown soon joined Williams and Corrigan and brought a new sophistication to the leadership's non-violent vision. After the rallies subsided, McKeown intended for the movement to generate pressure through 'community politics' and new power-sharing arrangements, but he also envisioned changes in hearts and minds.

6 https://web.archive.org/web/20150808153426/http://beautifultrouble.org/theory/ revolutionary-nonviolence/. 
Williams and Corrigan remained the central spokespeople, but McKeown (1976) penned the Peace People Declaration and a pamphlet entitled The Price of Peace, in which he framed the movement's potential and long-term goals. It is in McKeown's writings that one often finds calls to principled non-violence, such as those enumerated in the Gandhian template above.

\section{Use of Spiritual, Metaphysical, or Religious Tenets}

Northern Ireland is a highly religious region within Europe, and the three primary leaders often drew on Christian theology and practice, especially Corrigan and McKeown. They spoke in familiar religious terms, and they used theological principles to emphasize the importance of non-violence and the oneness of humanity. McKeown (1976:14) wrote, 'If you believe in God, you will already know your own value as a divinely created person with the possibility of a divine destiny [...] you will know that you must have an equal respect and love for his other creatures'. Mairead Corrigan, a devout Catholic, often drew on her faith and spoke of love and forgiveness as she did in her regular column in the movement newsletter, Peace by Peace.

\section{Non-violence Is Morally Superior}

McKeown highlighted the virtue of non-violence and emphasized the need for courage to carry out principled non-violence: 'Both logically and emotionally, it takes far more courage to be prepared to die, but never to kill, than it takes to be prepared to kill and take your chance on dying' (1976: 3). Courage emerges as a recurring virtue that Williams, Corrigan, and McKeown associated with non-violence. In their Noble Peace Prize lecture, Williams and Corrigan (1977) contrasted global militarism and military expenditures with courageous non-violence:

We know that this insane and immoral imbalance of priorities cannot be changed overnight: we also know that it will not be changed without the greatest struggle [...] And that struggle must be all the greater because it has to be an unarmed, a nonviolent struggle, and requires more courage and more persistence than the courage to squeeze triggers or press murderous buttons.

In this excerpt, Williams and Corrigan frame non-violent action as courageous (and difficult) and imply by contrast that violence is easy and cowardly. 


\section{Non-violence as a Lifestyle}

Applying non-violent philosophy in all areas of one's life coincided with the movement's goal of transforming society from the bottom up. Whether dealing with domestic conflicts in the home (McKeown 1976: 18) or working to build the movement, one's commitment to non-violence required continuous discipline. According to McKeown (1976:3), 'the genuine pacifist is engaged in a battle every day of his life'. In the 20 May 1977 issue of the movement's newspaper, nearly a full page was dedicated to an article about the Community of the Ark (L'Arche), a non-violent community in France, where,

To become the instrument of non-violence and unity, intelligence and affections must be constantly renewed and animated by Truth and Living Love [...] This is why the members of the non-violent community must seek together every day the spiritual strength in which they may find comfort, surmount their oppositions and live in a practical unity which reaches out to every person, even an adversary. (_.1977:5)

While the Community of the Peace People did not develop communal living, the basic principle of daily commitment was consonant with the bottom-up transformation of Northern Ireland that lay at the heart of the leadership's programme.

\section{New Societal Paradigms}

Advocates of principled non-violence focus not only on the means of nonviolent struggle but also on non-violent ends of more peaceful and just economic, political, and social relationships. McKeown criticized Northern Ireland's limited 'party-political' system and its inability to provide a solution to the Troubles. He felt any sustainable peace process would be produced from the grass roots. Only by transforming sectarian impulses at the individual and community level could a consensus be built. McKeown (1976) also felt the energy of the movement provided an opportunity to create an entirely new and unprecedented political system, an 'optimum' democracy (McKeown 1976: 27). Moreover, McKeown's transformationist vision called for a revolutionary new society distinguished by 'peace culture’:

Those with a deep interest in peace beyond a mere end to violence will have a special role in helping to create a 'peace culture' which will 
compete with and finally replace the received and meekly accepted cultural tradition with its violent tones, undertones and overtones. In short, we are attempting nothing less than the creation of a new civilization (1976: 28).

Campaigns were proposed to reform policies, such as police interrogation practices and Diplock courts, and to institute corrective policies, such as emergency status for prisoners charged under the Emergency Provisions Act. Together, they reflected the call for a new vision of a just future.

\section{Oneness of Humanity and Separating the Doer from the Deed}

Principled non-violence is often underpinned by a belief in a fundamental equivalence (and sometimes even metaphysical unity) of all humans, challenging processes of dehumanization that legitimate violence. McKeown touched on the oneness of humanity in his recognition of divinity in all humans, but more often, he emphasized Western concepts of individual liberties that all people share. Corrigan, writing in the Peace by Peace newspaper, declared that in the afterlife, 'I will be judged as a child of the universe and on my capacity to love all men of all nations' (Corrigan 1978:3).

A universalist position on the unity of all humans that considers humanity fundamentally good requires a way to distinguish humanity from destructive human behaviour and provide a pathway to atonement. McKeown and his successor as chairman of the Peace People Executive, Peter McLachlan, agreed that an authentic peace process, and ultimately reconciliation, would require involving ex-combatants from all sides and differentiating perpetrators from their violent actions in order to incorporate them into a new emerging society. As editor of Peace by Peace, McKeown published pieces by Gusty Spence, an imprisoned leader of the loyalist Ulster Volunteer Force paramilitary, and he foresaw a time when those, like Spence who had previously been involved in violence, should be released from prison (McKeown 1984: 188).

\section{Aligning Principled and Revolutionary Non-violence with Northern Ireland Culture}

Why did the movement decline? A complete answer lies beyond the scope of this chapter. I propose, as only one factor, that many who participated in the rally phase could not fully embrace the revolutionary scope of the 
programme formulated by the movement's leadership. McKeown's philosophy of non-violence constituted not only a set of strategies for achieving a conventional political end. He proposed a redefinition of the entire political structure and human relations in Northern Ireland.

Northern Ireland's unique historical context, including its divided political system and the traumatized collective psyche of the region, generated both opportunities and constraints for the movement. According to Fairmichael (1987:3), a genuine political vacuum was left in the wake of politicians' failures to establish a power-sharing government in 1973 . Moreover, the deaths of the Maguire children further dramatized the daily violence of the Troubles, evoking a public sense of outrage. Deutsch (1977), Fairmichael (1987), McKeown (1976: 11), and McKeown (1984) each noted a war-weariness or demoralization hanging over the region that reached a critical mass as the Peace People emerged (Deutsch 1977: 24). Unemployment had risen to record levels, and rates of violent deaths and injuries had risen to levels not seen since 1972 (Fairmichael 1987). As McKeown (1984: 139) describes, 'Violence was consuming itself, it seemed, and could beget no more violence [...] A volcano working up from the depths of the communal soul was looking for an outlet'. The bold and unconventional responses of Betty Williams and Mairead Corrigan provided an outlet for a collective frustration that had been building.

Even though Northern Ireland's troubled past provided an impetus for the Peace People, the context in which a movement emerges can also constrain it. Herein, one finds an important paradox in the emergence and maintenance of the Peace People. The non-violent nature of the movement made it appealing to the war-weary citizens of Northern Ireland. Yet, in the long run, the extensive commitment to principled and revolutionary non-violence proved unsustainable, because the Peace People's leaders were unable to align their non-violent praxis with the culture and experience of the people of Northern Ireland.

As Eyerman and Jamison (1991) point out, the ability of movement intellectuals to convey a movement's ideological foundation is important to the movement's capacity to establish and maintain itself. More importantly, a movement's ideology only has significant meaning when the meaning is collectively attributed or assigned (Kane 2011). Structural and cultural conditions hindered widespread adoption of an elaborate and radical programme of revolutionary non-violence and political transformation in Northern Ireland.

Ethnonational identities in Northern Ireland constitute important 'crosscutting solidarities' that can inhibit movement (McAdam, McCarthy, and 
Zald 1988), and the Peace People drew support from a divided constituency harbouring divided loyalties. Consequently, the Peace People's ideology tended to conflict with pervasive local configurations of identity fields. Among Peace People participants, ethnonational loyalties varied in intensity, but they persisted. McAdam, McCarthy, and Zald (1988: 704) argue that the greater the number and strength of such cross-cutting ties, the less likely a social movement will be able to emerge. As McAdam (1982: 49) argued when he introduced micro-mobilization processes to the study of social movements, 'It is not simply the extent and speed with which insurgency is spread but the very cognitions on which it depends that are conditioned by the strength of integrative ties within the movement's mass base'. It is equally true that once a social movement emerges, cross-cutting solidarities may also serve to precipitate its decline, especially when movement participants are already culturally predisposed to segregation (Bardon 1992: 727; Gamson 1995). The principled and revolutionary non-violent ideology of the Peace People became problematic as their leaders sought to redefine boundaries in Northern Ireland in radically egalitarian ways.

There are surely several reasons for the waning local support and the eventual decline of the Peace People during the movement's second phase. These include frayed relationships, financial problems, and misconceptions regarding the leadership's international roles (Fairmichael 1987; Walker 1978). ${ }^{7}$ However, events during the second phase and appraisals by observers and participants indicate that the goals of the movement, derived from principled and revolutionary non-violence, proved unacceptable to a significant portion of the movement's potential supporters. Movement participants were constantly confronted with the incongruity between their experience and the official non-violent vision for the movement. Richard Deutsch (1977: 175), who observed and documented the movement, offers this 'critical evaluation':

In many ways, the Northern Irish were not ready for the ideas of the Peace People. They were astonished by the plans, the scope of the program and of the thinking behind it. They must make a mental adjustment. They wanted peace, almost an immediate peace, a 'natural' peace without problems and without sacrifices. Then along came the Peace People and overwhelmed them with new thoughts and grandiose projects. Instead of bringing ready-made solutions, they asked for an extra effort, a collective

$7 \quad$ Further scholarly historiography of the movement could expand on Fairmichael's (1987) investigation and serve to elevate these factors in subsequent analyses. 
effort and, above all, a personal effort. And that, no doubt, is why the movement has met with so much resistance.

McKeown also found that the commitment of the movement's leaders to a radical philosophy of non-violence proved problematic:

By and large, in our early declarations of purpose, we were benignly dismissed as naive idealists, who might be forgiven such aberrations as nonviolence, in favour of the excellent promotional job we were otherwise doing. It would be much later, as it became clearer that nonviolence was the be-all and end-all of our commitment, that benign patronisation would give way more generally to irate opposition. (McKeown 1984: 177)

A couple of Ciaran McKeown's proposals for Peace People action demonstrate internal disconnects between what Fairmichael (1987:43) characterizes as the 'prophetic' (or revolutionary) project of non-violence backed by the leaders and the 'quieter project work' on which others wanted to focus.

First, contention over the treatment of prisoners held under the terms of the Emergency Provisions Act presented a significant stumbling block. Secretary of State Merlyn Rees withdrew 'special category status' for prisoners convicted of crimes after 1 March 1976. Republican prisoners protested this reversal, first by refusing to wear prison uniforms and then by refusing to use the sanitary facilities and smearing their own faeces on the walls of their cells. McKeown proposed that the issue be resolved by establishing an 'emergency status' for prisoners charged under the Emergency Act. Thus, those with extensive sentences established under the emergency situation would not be subject to the sentences indefinitely once the emergency ended. For McKeown (1984: 250), the prison issue was a crucial one on which the trajectory of the conflict could depend. It 'was the very touchstone of our seriousness as a peace movement seeking to work at the heart of the conflict'. The Peace People Assembly backed the proposal during its conference in October 1978, but for many Peace People, focusing on the politically charged prison issues amounted to 'becoming political' and risked upsetting the reconciliation work with which they were more comfortable. Others simply could not stomach extending any sort of relief to those they considered convicted terrorists (? 1978: 8).

Others found the international focus of McKeown, Williams, and Corrigan too ambitious or distracting. McKeown (1984:221-224), in particular, felt that Peace People groups should be actively involved in solidary relationships with other peace groups around the world as an appropriate expression of 
the unity of humanity. 'It seemed to me that we could not seriously tackle Northern Ireland's problems with the appropriate non-violent strategy and determination, if we did not have a constant, relentless appreciation that every human life is sacred: and that understanding dictated an immediate and active concern about "Third World" conditions' (1984: 223) (cf. Lakey 1973: 75-76). Hazel Senior of the Holywood Peace Group described the disconnect over international solidarity in an interview with Rob Fairmichael (1987:39):

Some of our people are very much if I may use the phrase, into nonviolence, and this means that perhaps they are just as involved in the non-violent aspect worldwide. For others I feel that they're interested in peace in Northern Ireland and that nonviolence might come into their vocabulary equally. I think in some ways people regard it as an academic thing.

These sorts of disputes represent a problem with framing and collective attribution, an inability of movement intellectuals to reconcile their radical non-violent philosophy with participants' understandings of reality. After all, framing is only one part of an interactive process of meaning making within social movements as participants experience, interpret, and internalize discourses over time from within their own socio-economic, cultural, and historical contexts (Kane 2011). As the Peace People emerged in a flash of weary frustration at the height of the Troubles and the three main leaders assumed such prominent roles, there was less opportunity for a more organic development of the movement's claims.

\section{Conclusion}

Collective identities play central roles in both ethnonational conflicts and social movements. Conflict, whether violent or non-violent, can deepen and polarize ethnonational boundaries, but some movements call for realignments of identities and social structures (see Nagle, in this volume). Nevertheless, each social movement emerges within its own political and historical context, and its praxis competes with other contradictory and established identities and ideological commitments. Careful framing can take advantage of the malleable nature of identities and introduce new models of identification that rearrange or transcend normal boundaries. However, new models introduced in moments of social movement can also prove too radical. To the extent that leaders' goals contradict or challenge 
prevailing identities and habitus, social movement organizations will find recruiting and retaining participants challenging.

The Peace People in Northern Ireland emerged in a society marked by deep social, political, cultural, and psychological divisions. Many citizens opened to new ideas of reconciliation and social change during the rally phase of the movement. McKeown, Corrigan, and Williams envisioned an unprecedented, totally inclusive, and non-violent society, a radical democracy that would arise from individuals deeply committed to principled non-violence and aligned with a global network of solidary movements, but Northern Ireland presented a difficult environment within which to establish and maintain support for a movement based on a combination of principled and revolutionary non-violence, especially once the effervescence of the early rallies faded. The scope of the leaders' goals exceeded the immediate desire for an end to violence and required a reconfiguration of world views extensive enough that their programme could not maintain broad support. For some, the immediacy of the Troubles trumped international solidarity, for others their views on justice precluded the call to reintegrate ex-combatants, and still others could not reconcile the poles of principled and revolutionary non-violence when called on to intervene and restructure the political system. These disconnects on matters of policy signal a deeper problem in meaning making at the intersection of framing and collective attribution.

\section{Works Cited}

_.1977. "The Community of the Ark: An Experience of Non-violent Society”. Peace by Peace 2.5 (20 May): 5 .

_. 1978. "An Open Letter to the Editor and Members of the Executive". Peace by Peace 3.18 (29 September): 8 .

Bardon, Jonathan. 1992. A History of Ulster. Belfast: Blackstaff Press.

Corrigan, Mairead. 1978. 'Irish, British, Northern Irish or 'A Child of the Universe'. Peace by Peace 3.20 (27 October)

Deutsch, Richard. 1977. Mairead Corrigan, Betty Williams. Woodbury, NY: Barron's Educational Series.

Eyerman, Ron, and Andrew Jamison. 1991. SocialMovements: A Cognitive Approach. University Park: Pennsylvania State University Press.

Fairmichael, Rob. 1987. 'The Peace People Experience'. Dawn Train 5.

Gamson, William A. 1995. 'Hiroshima, the Holocaust, and the Politics of Exclusion: 1994 Presidential Address'. American Sociological Review 60: 1-20. 
Gandhi, M.K. 1962. The Essential Gandhi, ed. Louis Fischer. New York: Vintage Books.

Gandhi, M.K. 1967. The Mind of Mahatma Gandhi, ed. R.K. Prabhu and U.R. Rao. Ahmedabad: Navajivan Publishing House.

Gandhi, M.K. 1986. The Moral and Political Writings of Mahatma Gandhi, vol. 2, Truth and Nonviolence, ed. Raghavan Iyer. Oxford: Clarendon Press.

Geddes, Diana. 1976a. 'Dispute Over Security in Northern Ireland Denied'. The Times (London), August 16, p. 2.

Geddes, Diana. 1976b. 'Mr. Rees Would Like Mrs. Drumm to Be “Locked up"'. The Times (London), August 3o. p. 3.

Hunt, Scott A., Robert D. Benford, and David A. Snow. 1994. 'Identity Fields: Framing Processes and the Social Construction of Movement Identities'. In New Social Movements, ed. Enrique Laraña, Hank Johnston, and Joseph R. Gusfield. Philadelphia: Temple University Press, 185-208.

Jenkins, Richard. 2008. Social Identity. New York: Routledge.

Kane, Anne. 2011. Constructing Irish National Identity: Discourse and Ritual during the Land War, 1879-1882. New York: Palgrave Macmillan.

Kurtz, Lester R. 2008. 'Gandhi and His Legacies'. In Encyclopedia of Violence, Peace \& Conflict, ed. L.R. Kurtz. $2^{\text {nd }}$ ed. London: Elsevier, 837-851.

Lakey, George. 1973. Strategy for a Living Revolution. New York: Grossman.

McAdam, Doug. 1982. Political Process and the Development of Black Insurgency, 1930-1970. Chicago: University of Chicago Press.

McAdam, Doug, John D. McCarthy, and Mayer N. Zald. 1988. 'Social Movements'. In The Handbook of Sociology, ed. Neil J. Smelser. Newbury Park, CA: Sage, 695-737.

McKeown, Ciaran. 1976. The Price of Peace. Belfast: Ciaran McKeown.

McKeown, Ciaran. 1984. The Passion of Peace. Belfast: Blackstaff Press.

Meyer, Matt. 2014. 'Rebuilding Revolutionary Nonviolence in an Anti-Imperialist Era'. Peace Review: A Journal of Social Justice 26:1, 69-77.

Smithey, Lee A. 2009. 'Social Movement Strategy, Tactics, and Collective Identity'. Sociology Compass 3: 658-671.

Smithey, Lee A. 2011. Unionists, Loyalists, and Conflict Transformation in Northern Ireland. Oxford: Oxford University Press.

Todd, Jennifer. 2005. 'Social Transformation, Collective Categories, and Identity Change'. Theory and Society 34: 429-463.

Walker, Christopher. 1976a. 'IRA Threatens Peace Supporters after Rise in Information to Security Forces'. The Times (London), 27 August, p. 1.

Walker, Christopher. 1976b. 'Coming Weeks Will Show Whether New Ulster Peace Movement Can Have Lasting Influence'. The Times (London), 6 September, p. 2. Walker, Christopher. 1978. 'Peace Movement Loses Local Support as Criticism Increases'. The Times (London), 17 April, p. 2. 
Weber, Thomas. 2003. 'Nonviolence Is Who? Gene Sharp and Gandhi'. Peace and Change 28: 250-270.

Williams, Betty and Mairead Corrigan. 1977. 'Nobel Lecture, December 11, 1977'. https://www.nobelprize.org/nobel_prizes/peace/laureates/1976/ williams-lecture_en.html.

Wimmer, Andreas. 2008. 'The Making and Unmaking of Ethnic Boundaries: A Multilevel Process Theory'. American Journal of Sociology 113: 970-1022.

Woehrle, Lynne M., Patrick G. Coy, and Gregory M. Maney. 2008. Contesting Patriotism: Culture, Power, and Strategy in the Peace Movement. Lanham, MD: Rowman \& Littlefield. 